\title{
Nosography of the "essential"
}

\section{Volitional palatal tremor}

白

\begin{tabular}{|c|c|c|c|}
\hline $\begin{array}{c}\text { Secondary } \\
\text { (SPT) }\end{array}$ & \multicolumn{3}{|c|}{ "Essential" (EPT) (isolated palatal tremor) } \\
\hline Myorhythmia & Psychogenic EPT & Secondary EPT & Volitional EPT \\
\hline Involuntary & $\begin{array}{l}\text { Anti-voluntary } \\
\text { (A-volitional) }\end{array}$ & $\begin{array}{c}\text { Unvoluntary } \\
\text { (Semi-volitional) }\end{array}$ & $\begin{array}{c}\text { Voluntary } \\
\text { (Fully volitional) }\end{array}$ \\
\hline $\begin{array}{l}\text { Associated , } \\
\text { dysarthria, } \\
\text { nystagmus, } \\
\text { and ataxia }\end{array}$ & $\begin{array}{l}\text { Non-organic features } \\
\text { besides ear click }\end{array}$ & & $\begin{array}{l}\text { ssociated features } \\
\text { pt ear click }\end{array}$ \\
\hline $\begin{array}{l}\text { Lesions in the } \\
\text { dentato- } \\
\text { olivary } \\
\text { pathway } \\
\end{array}$ & $\begin{array}{l}\text { Conversion disorder } \\
\text { Somatoform disorder }\end{array}$ & $\begin{array}{c}\text { Tics } \\
\text { Peripheral/mechanical }\end{array}$ & $\begin{array}{l}\text { "Special skills" } \\
\text { Voluntary control }\end{array}$ \\
\hline
\end{tabular}

"Essential" palatal tremor (EPT) can be distinguished from the slow tremor (myorhythmia) of secondary palatal tremor (SPT) by the lack of associated neurologic deficits. EPT, in turn, can be segregated into 3 overlapping clinical variants, as inspired by the nosography proposed by Zadikoff, Lang, and Klein²: psychogenic EPT, where a variable and suppressible tremor occurs against the will ("anti-voluntary"); secondary EPT, partially volitional and temporarily suppressible ("un-voluntary"); and volitional EPT, where there is complete control and no disability (patient reported here).

Supplemental data at www.neurology.org
A 19-year-old heavy metal singer with a history of congenital micrognathia, posttraumatic stress disorder, and anxiety developed isolated movements of the soft palate after lower mandible corrective surgery (osteotomy and genioplasty). He endorsed ear clicks and control over the movements. On examination, there were rhythmic movements of the distal soft palate, characteristic of essential palatal tremor (EPT). However, their change in frequency and amplitude on command (video on the Neurology ${ }^{\circledR}$ Web site at www.neurology.org) indicated volitional control. Unlike psychogenic EPT, whereby variability and entrainability must be present ${ }^{1}$ and endorsed as involuntary ("a-volitional"), patients with volitional EPT admit to full control and no disability (figure). They have also been categorized as the "voluntary/special skill" EPT variant. ${ }^{2}$ No neurologic investigations are warranted in patients with volitional EPT.

\section{Jose Biller, MD, FACP, FAAN, FAHA, Alberto J. Espay, MD, MSc, FAAN}

From the Department of Neurology (J.B.), Loyola University Chicago Stritch School of Medicine Maywood, IL; and UC Neuroscience Institute (A.J.E.), Department of Neurology, Movement Disorders Center, University of Cincinnati, OH.

Author contributions: Jose Biller: drafting/revising the manuscript, study concept or design, analysis or interpretation of data, accepts responsibility for conduct of research and gave final approval, acquisition of data, study supervision. Alberto J. Espay: drafting/revising the manuscript, study concept or design, analysis or interpretation of data, accepts responsibility for conduct of research and gave final approval, study supervision.

Study funding: No targeted funding reported. 
Disclosure: J. Biller reports no disclosures. A. Espay is supported by the K23 career development award (NIMH, 1K23MH092735); has received grant support from CleveMed/Great Lakes Neurotechnologies, Davis Phinney Foundation, and Michael J Fox Foundation; has received personal compensation as a consultant/scientific advisory board member for Solvay (now Abbvie), Chelsea Therapeutics, TEVA, Impax, Merz, Solstice Neurosciences, Eli Lilly, and USWorldMeds; and has received honoraria from Novartis, UCB, TEVA, the American Academy of Neurology, and the Movement Disorders Society. He serves as Associate Editor of Movement Disorders and Frontiers in Movement Disorders and on the editorial board of The European Neurological Journal. Go to Neurology.org for full disclosures.

Correspondence to Dr. Espay: alberto.espay@uc.edu

1. Stamelou M, Saifee TA, Edwards MJ, Bhatia KP. Psychogenic palatal tremor may be underrecognized: reappraisal of a large series of cases. Mov Disord 2012;27:1164-1168.

2. Zadikoff C, Lang AE, Klein C. The "essentials" of essential palatal tremor: a reappraisal of the nosology. Brain 2006;129: $832-840$.

\section{NeuroImages Are Free at www.neurology.org!}

All Neurology ${ }^{\circledR}$ NeuroImages can now be freely accessed on the Neurology Web site. See them at www.neurology.org, where you can also sign up for journal email alerts and check out other online features, including the Resident \& Fellow section, Neurology: Clinical Practice, and the weekly Neurology Podcasts.

\section{This Week's Neurology ${ }^{\circledR}$ Podcast}

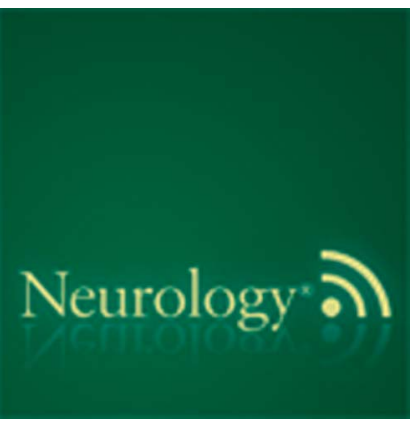

Electronic media in neurology education: Progress, promise, and pitfalls (See p. e47)

This podcast begins and closes with Dr. Robert Gross, Editor-inChief, briefly discussing highlighted articles from the August 20, 2013, issue of Neurology. In the second segment, Dr. Andy Southerland talks with Dr. Shaheen Lakhan about his paper on electronic media in neurology education. Dr. Adam Numis then reads the e-Pearl of the week about hemifacial spasm. In the next part of the podcast, Dr. Brandy Matthews focuses her interview with Dr. Bill Seeley on diagnostic testing and genetics in frontotemporal degeneration. Disclosures can be found at www.neurology.org.

At www.neurology.org, click on the "Download Latest Issue" link or "Subscribe Now" to subscribe to the RSS Feed.

CME Opportunity: Listen to this week's Neurology Podcast and earn 0.5 AMA PRA Category 1 CME Credits ${ }^{\mathrm{TM}}$ by answering the multiple-choice questions in the online Podcast quiz. 


\title{
Neurology
}

\author{
Nosography of the "essential": Volitional palatal tremor \\ Jose Biller and Alberto J. Espay \\ Neurology 2013;81;772-773 \\ DOI 10.1212/WNL.0b013e3182a1aab3
}

This information is current as of August 19, 2013

\begin{tabular}{|c|c|}
\hline $\begin{array}{l}\text { Updated Information \& } \\
\text { Services }\end{array}$ & $\begin{array}{l}\text { including high resolution figures, can be found at: } \\
\text { http://n.neurology.org/content/81/8/772.full }\end{array}$ \\
\hline Supplementary Material & $\begin{array}{l}\text { Supplementary material can be found at: } \\
\mathrm{http} / / / \text { n.neurology.org/content/supp1/2013/08/14/81.8.772.DC1 }\end{array}$ \\
\hline References & $\begin{array}{l}\text { This article cites } 2 \text { articles, } 0 \text { of which you can access for free at: } \\
\text { http://n.neurology.org/content/81/8/772.full\#ref-list-1 }\end{array}$ \\
\hline Subspecialty Collections & $\begin{array}{l}\text { This article, along with others on similar topics, appears in the } \\
\text { following collection(s): } \\
\text { Clinical neurology examination } \\
\text { http://n.neurology.org/cgi/collection/clinical_neurology_examination } \\
\text { Tremor } \\
\text { http://n.neurology.org/cgi/collection/tremor }\end{array}$ \\
\hline Permissions \& Licensing & $\begin{array}{l}\text { Information about reproducing this article in parts (figures,tables) or in } \\
\text { its entirety can be found online at: } \\
\text { http://www.neurology.org/about/about_the_journal\#permissions }\end{array}$ \\
\hline Reprints & $\begin{array}{l}\text { Information about ordering reprints can be found online: } \\
\mathrm{http} / / / \text { n.neurology.org/subscribers/advertise }\end{array}$ \\
\hline
\end{tabular}

Neurology ${ }^{\circledR}$ is the official journal of the American Academy of Neurology. Published continuously since 1951, it is now a weekly with 48 issues per year. Copyright @ 2013 American Academy of Neurology. All rights reserved. Print ISSN: 0028-3878. Online ISSN: 1526-632X.

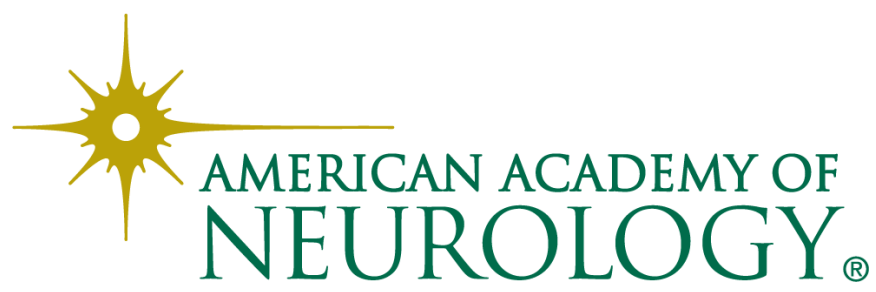

